\title{
MODEL WRITING WORKSHOP \\ DALAM PENULISAN PROPOSAL SKRIPSI MAHASISWA DEPARTEMEN PENDIDIKAN BAHASA DAERAH FPBS UPI
}

\author{
Hernawan, Temmy Widyastuti, Haris Santosa Nugraha \\ Departemen Pendidikan Bahasa Daerah FPBS UPI
}

Pos-el: hernawan@upi.edu; temmy.widyastuti@upi.edu; harissantosa89@upi.edu

\begin{abstract}
Abstrak
Penelitian ini dilatarbelakangi oleh kemampuan menulis proposal skripsi mahasiswa Departemen Pendidikan Bahasa Daerah FPBS yang masih rendah, karena belum ada model pembelajaran menulis proposal skripsi yang tepat. Oleh karena itu, perlu adanya model pembelajaran menulis proposal skripsi yang efektif dan efisien. Tujuan penelitian ini adalah untuk mendeskripsikan kemampuan menulis proposal penelitian (skripsi) mahasiswa sebelum dan setelah menggunakan model writing worshop. Metode yang digunakan dalam penelitian adalah kuasi eksperimen dengan sumber data 55 mahasiswa. Berdasarkan hasil penelitian rata-rata pretest diketahui 66,00 dan ratarata posttest sebesar 83,18, dengan t hitung adalah 27,755. Maka, dapat disimpulkan adanya perbedaan yang signifikan antara kemampuan mahasiswa dalam menulis proposal skripsi sebelum dan setelah menggunakan model writing workshop. Jadi, dapat disimpulkan bahwa model Wiritng Workshop dapat meningkatkan kemampuan menulis proposal skripsi mahasiswa Departemen Pendidikan Bahasa Daerah FPBS Tahun Akademik 2017-2018.
\end{abstract}

Kata Kunci: writing workshop, proposal skripsi.

\section{WRITING MODEL WORKSHOP \\ IN STUDENTS'PROPOSAL WRITING AT THE DEPARTMENT OF SUNDANESE LANGUAGE EDUCATION OF FPBS UPI}

\begin{abstract}
This research is motivated by the ability to write thesis proposal of the Department of Sundanese Language Education Department of FPBS which is still insufficient, because there is lack of learning model of appropriate writing thesis proposal. Therefore, it is necessary to have a learning model of writing an effective and efficient thesis proposal. The purpose of this study is to describe students' ability to write research thesis proposals before and after utilizing writing model workshop. The method used in this research is quasi experiment involving 55 students as data source. Based on the result of research, it showed that pretest score average is 66,00 and post test score average equal to 83,18, with 27,755 t count. Thus, it can be assumed that there is a significant difference between the ability of students in writing thesis proposal before and after utilizing writing workshop model. Thus, it can be concluded that writing workshop model can improve students ability to write thesis proposal in the Department of Sundanese Language Education of FPBS in 2017-2018 academic year.
\end{abstract}

Keywords: writing workshop, thesis proposal. 


\section{PENDAHULUAN}

Menulis adalah kegiatan yang memerlukan tingkat konsentrasi dan daya nalar yang baik. Kegiatan menulis di perguruan tinggi tidak hanya terbatas dalam menulis makalah dan jurnal saja, tapi mahasiswa harus mengerjakan juga proposal skripsi, dalam hal ini mahasiswa dituntut untuk memiliki kemampuan dalam mencerna berbagai sumber referensi yang dibutuhkan dalam menulis proposal skripsi. Kemampuan ini merupakan bentuk pengembangan diri mahasiswa, dalam melanjutkan studi ke tingkat yang lebih tinggi maupun untuk terjun ke dalam masyarakat (Sutari, 1997).

Kemampuan menulis proposal yang baik sangat dibutuhkan oleh mahasiswa karena memilki banyak peluang yang menguntungkan, salahsatunya mendapat berbagai kesempatan penelitian yang didanai oleh perguruan tinggi, pemerintah dan pihak swasta (Akhadiah, 1997). Maka dari itu mahasiswa harus dilatih untuk bisa mengkomunikasikan gagasan, penghayatan, perasaan, kehendak, dan pengalamannya ke dalam bentuk penelitian. Tidak mudah melatih mahasiswa dalam mengorganisasikan suatu penelitian terlebih dalam merancang proposal penelitian, masalah yang dihadapi mahasiswa adalah sulit dalam mengemukakan masalah, pendapat, juga berbagai asumsi dalam penelitian. Selain itu, masalah lainnya seperti bagaimana cara memanfaatkan modelmodel pembelajaran yang efektif dan efisien yang bisa digunakan untuk menyelesaikan kesulitan mahasiswa dalam menulis proposal skripsi. Pemanfaatan dimaksud adalah bagaimana cara mengajarkannya ditinjau dari pihak dosen, dan cara mempelajarinya dari pihak mahasiswa.

Mahasiswa harus mengkonstruksikan pengetahuan di benak mereka sendiri. Para ahli sepakat bahwa pengetahuan yang dimiliki sesorang itu terorganisasi dan mencerminkan pemahaman yang mendalam tentang sesuatu persoalan. Tujuan menulis proposal skripsi adalah memberikan kesempatan kepada mahasiswa untuk memperoleh pengetahuan dan pengalaman menulis proposal yang benar dan sistematis. Pengetahuan dan pengalaman menulis proposal skripsi akan memperkuat kemampuan mahasiswa dalam memahami apa yang akan ditelitinya khususnya yang bertalian dengan bahasa Sunda, yaitu dengan mempertajam perasaan, penalaran, berfikir kritis, menumbuhkan kepekaan terhadap masyarakat, budaya, dan lingkungan untuk dikomunikasikan kepada orang lain.

Faktanya masih banyak mahasiswa yang mengikuti pembelajaran menulis proposal skripsi, tetapi mahasiswa tersebut tidak mendalami dan tidak memahami pembelajaran, bahkan ada juga mahasiswa yang tidak tertarik terhadap pembelajaran menulis proposal, karena merasa tidak bisa, dan tidak percaya diri. Kondisi seperti itu harus bisa ditanggulangi. Untuk itu, setidaknya ada tiga komponen yang harus diperhatikan oleh dosen dalam rangka mencapai tujuan pembelajaran menulis proposal skripsi. Ketiga komponen itu, yakni: komponen mahasiswa, komponen dosen, dan komponen bahan. Ketiga komponen inilah yang menjiwai writing workshop untuk membantu mahasiswa dalam meningkatkan kemampuan menulis proposal skripsi (Atwell, 2014).

Mahasiswa merupakan objek utama dalam kegiatan belajar mengajar. Mereka memiliki sejumlah kompetensi yang harus dikembangkan oleh dosen. Dosen sebagai fasilitator dalam kegiatan belajar mengajar harus mempunyai teknik yang tepat agar dapat menumbuhkembangkan potensi yang dimiki mahasiswa tersebut. Komponen ketiga adalah bahan menulis proposal skripsi. Bahan mengenai menulis proposal skripsi akan menjadi materi yang penting dalam perkuliahan penelitian jika bahan tersebut sudah dibaca dan dipahami oleh mahasiswanya.

Seorang dosen harus dapat menciptakan suasana belajar menulis proposal skripsi yang menarik, yang dapat menggugah mahasiswa untuk dapat merespon, menanggapi, dan mengkritisi. 
Melalui Model Writing Workshop apa yang dibutuhkan mahasiswa dan diinginkan dosen dapat terpenuhi. Writing Workshop dirancang untuk membantu mahasiswa dalam meningkatkan kemampuan menulis proposal skripsi. Model ini dikembangkan oleh National Writing Project di Amerika Serikat. Tidak hanya di luar model ini pun banyak dikembangkan di Indonesia, salahsatunya Fakultas Ilmu Budaya UGM pernah mengadakan pelatihan penulisan jurnal dengan menggunakan Writing Workshop (Fib.ugm.ac.id, 2017) dan penggunaan model tersebut menghasilkan produktivitas penulisan jurnal, hal senada diungkapkan (Mulyani, 2009) yang telah menggunakan Writing Workshop untuk meningkatkan kemampuan menulis bahasa Inggris, dan hal tersebut berhasil, kemampuan siswa dalam menulis bahasa Inggris menjadi semakin baik. Dengan menggunakan model Writing Workshop diharapkan mahasiswa bisa lebih memahami dan terampil dalam menulis proposal skripsi, sehingga hal tersebut dapat memudahkan mahasiswa dalam menulis skripsi.

\section{METODE}

Metode yang digunakan dalam penelitian ini adalah kuasi eksperimen dengan desain penelitian pretest and posttest design. Teknik yang digunakan dalam penelitian ini adalah teknik non-tes dan observasi. Instrumen yang digunakan dalam penelitian ini adalah perintah dan pedoman observasi. Desain penelitian sebagai berikut:

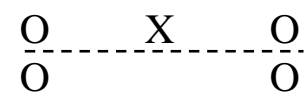

(Sugiyono, 2009)

Keterangan :

$\mathrm{O}$ : Tes Kemampuan penulisan proposal skripsi

$\mathrm{X}$ : Perlakuan dengan model writing workshop

Penelitian ini dilaksanakan di Departemen Pendidikan Bahasa Daerah FPBS UPI, sumber data dalam penelitian ini adalah mahasiswa semester 7. Mahasiswa yang dijadikan sampel dalam penelitian ini sebanyak 55 mahasiswa. Perhitungan nilai pretest dan posttest dihitung dengan menggunakan program SPSS.

\section{HASIL DAN PEMBAHASAN}

Model Writing Workshop memberikan kesempatan kepada mahasiswa untuk menulis proposal skripsi dengan berbagai tujuan dalam berbagai bentuk atau gaya. Model Writing Workshop memerlukan serangkaian aktivitas dalam menulis proposal skripsi. Rangkaian aktivitas itu dilakukan melalui beberapa fase yang dimulai dari 1) pemilihan topik yang akan ditulis (penelitian); 2) mahasiswa diminta untuk pergi ke luar kelas guna mempelajari dan mengobservasi sesuatu yang akan diteliti; 3) mahasiswa diarahkan pada masalah-masalah yang berkaitan dengan keagiatan menulis proposal skripsi akademik; dan 4) kegiatan kelas kembali ke fase pertama, yaitu menjadikan diri mahasiswa sebagai pusat proses menulis proposal skripsi dengan tahapan prewriting; drafting; revising; editing; sharing; dan pusblishing.

Kegiatan kolaborasi dalam menulis proposal skripsi akan lebih menantang ketika mahasiswa melakukan peer critique, peer editing, dan peer proofreading (Akhadiah, 1998) artinya mahasiswa akan saling memberikan kritik terhadap peneltian temannya lalu dilanjutkan dengan saling mengedit tulisan dan mulai membaca ulang hasil kajian mereka.

Menulis porposal skripsi membutuhkan keseriusan usaha dan latihan dalam menyusun, mengembangkan, dan menganalsis (Lensimire, 1994) apa yang akan mereka teliti. Writing workshop merupakan jantung keberhasilan menulis proposal penelitian karena masiswa belajar untuk berkoordinasi dalam mengemukakan ide penelitian (Rothatein, 1996). Dari hal tersebut mahasiswa langsung menulis proposal, lalu dosen memberikan nilai, dan dilanjutkan dengan perlakuan model Writing Workshop lalu mahasiswa menulis kembali proposal dan mereka mendapat nilai posttest. Berikut grafik hasil pretest dan posttest mahasiswa DPBD 
dalam menggunakan model Writing

Workshop.

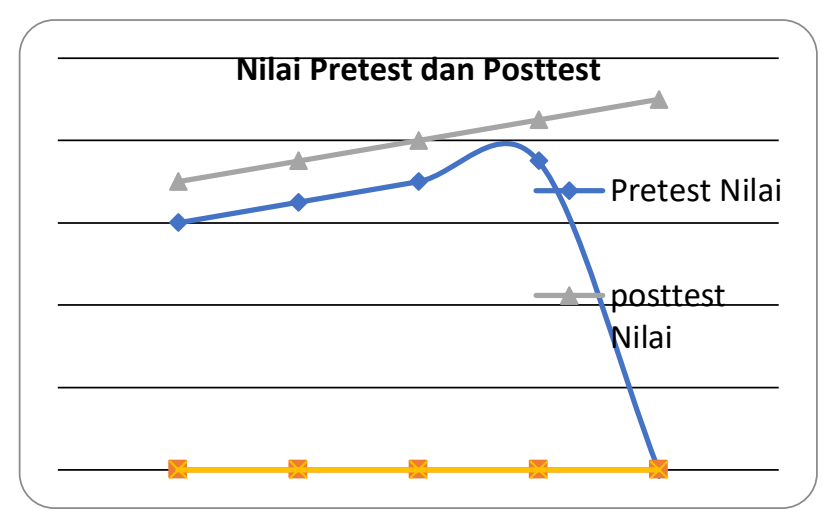

Terjadi peningkatan antara nilai pretest dan posttest. Penilaian pretest di atas didasarkan atas 3 hal, yaitu 1) dari segi isi yang mencakup kesesuaian judul penelitian dengan isi proposal; permasalahan yang diangkat; urgensi penelitian, dan referensi yang digunakan dalam penelitian; 2) dari segi tata bahasa dan organisasi penulisan yang mencakup struktur kalimat yang digunakan, ejahan yang baik dan benar, dan cara pendeskripsian yang jelas, tidak ambigu dan tepat sasaran; 3) dari segi luaran penelitian yang mencakup manfaat dari penelitian tersebut untuk perkembangan ilmu pengetahuan itu sendiri dan kegunaan untuk bidang pendidikan juga untuk lingkungan sekitar.

Kemampuan awal mahasiswa dalam menulis proposal skripsi mendapat rentang skor $60-75$ nilai tersebut didapat dari penilaian isi, tata bahasa, dan luaran penelitian. Dari 55 Mahasiswa, 29 mahasiswa mendapat rentang skor 60-65, dan 26 mahasiswa yang mendapat rentang skor 70-75, masih banyak mahasiswa yang mendapat skor 6065 dikarenakan masih banyak kekurangan dalam isi proposal, tata bahasa dan organisasi penulisan, juga luaran penelitian. secara eksplisit dideskripsikan:

1) Isi: kesulitan siswa dalam mencari judul yang tepat, tidaklah mudah bagi mahasiswa untuk menentukan judul pada awal penelitian, mahasiswa dibingungkan dengan bidang apa yang mereka kuasai, ketika sudah memilih satu bidang pun beberapa mahasiswa berpindah pada bidang lainnya dikarenakan tidak yakin akan bisa menyelesaikannya, hal tersebut terjadi karena pengaruh dari teman dan sumber yang dibaca.

2) Masalah dan teori yang digunakan, mahasiswa tidak memahami masalah yang akan diteliti, masalah tersebut dicari bahkan terkesan mengada-ngada, padahal seharusnya masalah yang terdapat dalam penelian adalah masalah yang terjadi di lapangan perlu kiranya pembimbing memberitahukan perihal teori dalam meneliti kepada mahasiswa. Sementara dalam mencari teori, mahasiswa dibingungkan dengan teori yang banyak, sehingga terdapat perbedaan antara teori yang ditulis dalam proposal dan teori analisis.

Referensi yang harus dibaca mahasiswa dalam penelitian haruslah sangat banyak dan beragam, selain itu referensi yang dicari pun adalah referensi terkini, walaupun referensi yang diambil itu boleh dari manapun dan tahun kapanpun, akan tetapi harus ada pembanding dengan referensi terbaru, karena ilmu pengetahuan akan terus berkembang, jadi tidak mungkin dalam sebuah penelitian semua referensi yang dipakai itu adalah referensi lama. UPI sendiri mewajibkan pengambilan referensi itu baik dari buku 
ataupun penelitian lainnya adalah 5 tahun terakhir dari tahun penelitian.

3) Ejahan dan organisasi karangan, banyak sekali letak kesalahan ketika mahasiswa mulai merangkai kalimat, baik itu dari penggunaan huruf kapital, dan dari sistem tanda baca, ketidaktelitian menjadi faktor utama terjadinya kesalahan ejahan, sedangkan permasalahan yang terjadi dalam mendeskripsikan kalimat adalah struktur kalimat yang digunakan adalah struktur dalam bahasa Indonesia. Hal tersebut akan memengaruhi makna secara utuh bahkan ada pula yang tidak dimengerti sama sekali karena beberapa mahasiswa melakukan penerjemaahan kata perkata.

4) Hasil penelitian dan pentingnya memahami luaran penelitian, tingkat keharusan suatu penelitian dan manfaat pengaplikasian sangatlah penting dalam sebuah penelitian. Pemahaman akan masalah akan berbanding lurus dengan hal urgensi dan luaran penelitian, penelitian yang baik adalah penelitian yang mampu menyelesaikan segala permasalahan di lapangan karena itu pengarahan diperlukan juga dalam pemilihan tema, judul, dan masalah dalam penelitian karena akan berujung pada kegunaan di lapangan. karena tidak mengobservasi dengan seksama penelitian yang penting untuk diteliti mengakibatkan hasil yang kurang bisa diaplikasikan dalam kehidupan sekitar bahkan untuk perkembangan ilmu pengetahuan itu sendiri.

Sementara hasil posttest mahasiswa DPBD setelah menggunakan model Writing Workshop meningkat dengan rentang skor 70-90. terdapat 13 mahasiswa yang mendapat skor 90, 16 mahasiswa dengan skor 85, 20 mahasiswa dengan skor 80, 5 mahasiswa dengan skor 75 dan seorang saja yang masih mendapat skor 70. Apabila dirata-ratakan lebih banyak mahasiswa yang mendapat skor 80-90. Beberapa siswa yang mendapat skor 70-75 dinilai sudah baik, namun masih banyak kekurangan referensi dalam pemaparannya.

Kenaikan skor posttest mahasiswa disebabkan beberapa hal, seperti yang telah disebutkan oleh (Atwell, 2014) model Writing Workshop adalah (a) pengajaran menulis proposal skripsi melibatkan proses personal dan sosial, (b) mahasiswa mempunyai kebebasan untuk memilih topik atau apa saja yang ingin ditulis, (c) proses pembelajaran menulis proposal skripsi difokuskan pada penciptaan makna, serta (d) hasil belajar sesuai dengan konteks yang ada, diitambah dengan prosedur observasi dan refleksi, juga proses editing yang dilakukan beberapa kali menjadikan mahasiswa lebih siap, sigap dalam menulis, mahasiswa terlatih untuk mencari berbagai sumber bacaan referensi untuk dikaji dan dimasukan ke dalam proposal skripsi.

Dari tiga aspek yang dinilai yaitu isi, tatabahasa dan organisasi penulisan, juga luaran penelitian, kemampuan mahasiswa lebih meningkat dalam hal tata bahasa dan organisasi penulisan, hal tersebut disebabkan oleh proses editing secara berkelanjutan. Dalam mengerjakan proposal skripsi dengan menggunakan model writing workshop mahasiswa dibagi ke dalam kelompok bahasa, pembelajaran, sastra, dan budaya, lalu setiap kelompok masing-masing telah mengumpulkan berbagai referensi bacaan hasil dari observasi yang dilkukan pada fase ke 2, mahasiswa bersama-sama mendiskusikan penelitiannya, dalam hal ini mahasiswa yang kurang membaca dan membawa sumber referensi menjadi terbantu dikarenakan proses diskusi perkelompok tersebut, tapi dari hasil posttest masih terdapat satu mahasiswa yang mendapat skor 70, dikarenakan tidak ada kemajuan antara sebelum dan sesudah menggukana model Writing Workshop, kendala yang dihadapi adalah menentukan permasalahan. Pada awalnya semua mahasiswa memiliki mindset mencari masalah ketika mereka melakukan observasi, artinya masalah tidak 
akan ditemukan ketika mahasiswa masih "mencari", hasilnya banyak mahasiswa pada tahap pretest kurang bisa merumuskan masalah bahkan cenderung mencari-cari masalah. Seharusnya masalah dalam penelitian itu adalah masalah yang ditemukan di lapangan dan masalah tersebut belum terselesaikan. Dari hal ini mahasiswa mulai memahami permasalahan yang ada sesuai dengan fakta lapangan. Maka dari itu judul proposal yang dibuat dan isi yang dijelaskan juga permasalahan yang dikemukakan menjadi satu-kesatuan yang saling berkaitan.

Skor tertinggi kedua setelah tata bahasa dan organisasi penulisan, adalah Isi. Isi proposal skripsi haruslah sesuai dengan judul yang dibangun, dalam model Writing Workshop dosen selalu membimbing mahasiswa selama proses penulisan, dengan adanya bantuan bimbingan menyeluruh, apa yang ditulisakan oleh mahasiswa akan sesuai dengan judul dan permasalahan yang ada, karena itu ketika hampir seluruh mahasiswa mendapatkan nilai yang baik dengan rentang skor 80-90. Dalam hal luaran penelitian, bukan berarti mahasiswa tidak memahami pengaplikasian dari penelitian yang dibuat, tetapi terdapat beberapa mahasiswa yang masih melakukan penelitian dengan kurang memperlihatkan luaran atau hasil dari penelitian tersebut termasuk manfaat di dalamnya. Tapi lebih dari itu mahasiswa sudah mampu mengorganisasikan ketiga aspek dalam proposal skripsi yang ditulis.

\section{Uji Perbedaan Kemampuan Penulisan Proposal Skripsi Pretest dan Posttes}

Sebelum melakukan uji perbedaan kemampuan penulisan skripsi mahasiswa, maka dilakukan uji sifat data yang Pired Samples Correaltion menujukan hasil korelasi antara kedua variabel yang menghasilkan angka 0.577 dengan nilai signifikan 0.000. hal ini menujukan bahwa korelasi antara kemampuan pratest dan mencakup uji normalitas, uji homogenitas, dan uji linearitas. Berdasarkan hasil uji normalitas (test of normality) pretest dan posttes menggunakan program SPSS menggunakan tafsiran KolmogorovSmirnov diperoleh nilai 1,247 dan Asymp. Sig. (2-tailed) adalah 0,089 $>0,05$. Berdasarkan hal tersebut dapat disimpulkan bahwa kemampuan penulisan proposal skripsi mahasiswa pretest dan posttest berdistribusi normal.

Hasil uji homogenitas ditemukan nilai signifikansi kemampuan penulisan proposal skripsi adalah $0,858>0,05$. Berdasarkan hal tersebut, maka bisa disimpulkan bahwa data diambil dari sampel yang homogen. Adapun hasil uji Linearitas ditemukan nilai signifikansi uji linearitas kemampuan penulisan proposal skripsi adalah 0,214 >0,05. Berdasarkan hal tersebut, maka bisa disimpulkan bahwa terdapat hubungan linear secara signifikan antara kemampuan pretest dan posttest.

Berdasarkan hasil uji sifat, data penelitian termasuk berdistribusi normal, diambil dari sampel yang homogen, dan memiliki hubungan yang linear. Maka uji perbedaan kemampuan penulisan proposal skripsi pretest dan posttest menggunakan statistik parametrik. Uji hipotesis parametrik dalam SPSS dilakukeun menggunakan uji paired sample t-test. Uji ini dilakukeun untuk menemukan adatidaknya perbedaan rata-rata dua sampel berpasangan.

Rata-rata pretest sebesar 66,00 dan rata-rata posttest sebesar 83,18, standar deviasi menujukan variasi data pada setiap variabel, standar deviasi pretest adalah sebesar 4,944 dan posttest sebesar 5.034, adapun $\mathrm{N}$ menunjukan banyaknya data yaitu 55.

postest adalah erat dan benar-benar berhubungan secara nyata. Adapun berdasarkan uji perbedaannya ditunjukan pada tabel di bawah ini. 


\begin{tabular}{|c|c|c|c|c|c|c|c|c|c|}
\hline \multicolumn{10}{|c|}{ Paired Samples Test } \\
\hline & & \multicolumn{5}{|c|}{ Paired Differences } & \multirow[t]{3}{*}{$\mathrm{t}$} & \multirow[t]{3}{*}{ Df } & \multirow{3}{*}{$\begin{array}{l}\text { Sig. (2- } \\
\text { tailed) }\end{array}$} \\
\hline & & \multirow[t]{2}{*}{$\begin{array}{c}\text { Mea } \\
\mathrm{n}\end{array}$} & \multirow[t]{2}{*}{$\begin{array}{l}\text { Std. } \\
\text { Deviati } \\
\text { on }\end{array}$} & \multirow[t]{2}{*}{$\begin{array}{l}\text { Std. } \\
\text { Error } \\
\text { Mean }\end{array}$} & \multicolumn{2}{|c|}{$\begin{array}{l}95 \% \text { Confidence } \\
\text { Interval of the } \\
\text { Difference }\end{array}$} & & & \\
\hline & & & & & Lower & Upper & & & \\
\hline $\begin{array}{l}\text { Pair } \\
1\end{array}$ & $\begin{array}{l}\text { Posttest - } \\
\text { Pretest }\end{array}$ & $\begin{array}{r}17.1 \\
82\end{array}$ & 4.591 & .619 & 15.941 & 18.423 & $\begin{array}{r}27.7 \\
55\end{array}$ & 54 & .000 \\
\hline
\end{tabular}

Tabel di atas menunjukan output hasil uji perbedaan rata-rata berpasangan dengan tingkat signifikansi $(\alpha)$ adalah $5 \%$ atau tingkat kerpercayaan 95\% df (degree of freedom) atau derajat kebebasan adalah n-1 atau 55-1=54. Uji dilakukan dua sisi atau dua ekor karena akan diketahui apakah rata-rata sebelum sama dengan sesudah ataukah tidak. Dari tabel t, didapat angka 27,755. Terlihat bahwa t hitung adalah 27.755 dengan nilai probabilitas 0,000 . Oleh karena probabilitas $0,000<0,05$, maka Ha diterima, yang berarti kemampuan penulisan proposal skripsi mahasiswa pretes dan posttest adalah tidak sama atau berbeda secara nyata atau signifikan.

Dari perhitungan uji sifat data di atas, dapat dibuktikan bahwa model Writing Workshop dapat meningkatkan kemampuan menulis proposal skripsi mahasiswa DPBD. Sejalan dengan penelitian lainnya, bahwa Writing Workshop dapat memudahkan kemampuan menulis karya ilmiah (Fib.ugm.ac.id, 2017; Mulyani, 2009)

\section{SIMPULAN}

Keberhasilan penggunaan model Writing Workshop tidak terlepas dari pengaruh tahapan pembelajaran, dengan konsep pembelajaran yang sistematis, mahasiswa mudah memahami apa yang disampaikan oleh dosen, terlebih dari tahapan-tahapan yang harus dilaksanakan oleh mahasiswa dimulai dari prewriting; drafting; revising; editing; sharing; dan pusblishing, menghasilkan proposal yang memuaskan. Berdasarkan hasil uji perbedaan rata-rata menggunakan program SPSS membuktikan bahwa ada perbedaan yang nyata antara kemampuan pretest dan posttes. Sehingga membuktikan bahwa penggunakan model Writing Workshop dapat meningkatkan kemampuan penulisan proposal skripsi mahasiswa DPBD FPBS UPI secara signifikan.

\section{PUSTAKA RUJUKAN}

Akhadiah, M.K. Sabarti, dkk. 1997. Menulis proposal skripsi. Jakarta: DIKDASMEN.

Akhadiah, M.K. Sabarti, dkk. 1998. Pengembangan Kemampuan Bernalar, Kreativitas, dan Budaya Tulis Melalui Jalur Pendidikan dalam Rangka Peningkatan SDM dalam Bahasa Indonesia Menjelang Tahun 2000. Jakarta: Depdikbud.

Atwell, Nancie. 2014. In the Middle: Writing, Reading, and Learning with Adolencents. Heinemann: United Kingdom.

Lensimire, Timothy J. 1994. When Children Write Critical Revisions of The Writing Workshop. New York: Teachers College, Columbia University.

Mulyani, Isye. 2009. Penerapan Model Writing Workshop Untuk Meningkatkan Kemampuan Menulis Bahasa Inggris Siswa Kelas XII IPS SMAN 11 Bandung. Jurnal Penelitian Vol. 10. No. 2. Oktober 2009.

Rothatein, Herbert M. 1996. Composition Workhsop. New York: Sadlier, Inc.

Sugiyono. 2009. Metode Penelitian. Pendidikan: pendekatan kuantitatif, kualitatif, dan R\&D. Bandung: Alfabeta.

Sutari, Ice dkk. 1997. Dasar-dasar Kemampuan Menulis. Bandung: FPBS IKIP: Bandung.

http://fib.ugm.ac.id/2017/10/writingworkshop-for-article-publication-inthe-international-jaournal.html 
UCAPKAN TERIMA KASIH

Terima kasih penulis sampaikan kepada semua pihak yang membantu penelitian ini, terutama kepada penyunting Jurnal Lokabasa yang sudah bersedia memuat tulisan ini. 